\title{
Research on Trial-design of Reactive Powder Concrete Footbridge
}

\author{
HUANG Qing-wei ${ }^{1,2}$, CHEN Bao-chun ${ }^{2}$ \\ ${ }^{1}$ College of Material Science and Engineering, Wuhan University of Technology, Wuhan, 430070, \\ China; \\ ${ }^{2}$ College of Civil Engineering, Fuzhou University, Fuzhou, 350108, China
}

Keywords: Footbridge; Reactive Powder Concrete (RPC); Trial Design; Structural Behaviors; Material Cost

\begin{abstract}
Reactive powder concrete (RPC) is a kind of cement-based composite material with super-high compressive strength, high toughness and good durability, which could be used for footbridge and make the bridge economic, aesthetic and durable. Taking a steel footbridge with a main span of $47 \mathrm{~m}$ as prototype, a trial design of RPC footbridge is conducted. Analysis results show that the RPC footbridge has a higher performance-price ratio; its girder materials only cost $61 \%$ of that in the original bridge. Compared with the PC footbridge, RPC bridge has higher structural behaviors, its concrete and external tendons decrease $56.4 \%$ and $18.2 \%$ respectively, which results to a reduction of $53.9 \%$ of the self-weight. Therefore, RPC footbridge has considerable application advantages and is feasible for practice.
\end{abstract}

\section{Introduction}

Reactive Powder Concrete (RPC) is a new type of cement-based composite materials made mainly up of cement, silica fume, quartz sand (powder), super-plasticizer and steel fiber. It has advantages such as super high strength, high toughness and low permeability [1-2]. The super-high strength of RPC makes structural smaller and dead weight lighter. Less material consumption, convenient construction, shorter project duration, and excellent durability allow the bridge with a low total cost in its service period, and application prospect. Several RPC footbridges have built up overseas, such as Sherbrooke Bridge in Canada [3], Seonyu Bridge in South Korea [4], Sakata-Mirai bridge [5] and three other bridges in Japan while an application of it has not yet been seen domestically.

To promote the application of domestic RPC footbridge, this paper takes a footbridge which has already been built as prototype to conduct an trial design of RPC footbridge. Analysis and comparisons among steel bridge, prestressed concrete (PC) bridge and RPC bridge will be conducted in terms of structural properties, work quantity and construction.

\section{Project background}

A footbridge should be across $30 \mathrm{~m}$ width Street, crowd load is $3.89 \mathrm{kPa}$. The main bridge is $5 \mathrm{~m}$ in width; the stairway is $4 \mathrm{~m}$ in width. The design basic earthquake intensity is 7 degrees; safety class rank is second, and design working life is 100 years.

Steel footbridge. The existing footbridge is a triply-span steel bridge, the spans are $18 \mathrm{~m}, 47 \mathrm{~m}$ and $18 \mathrm{~m}$; longitudinal gradient is $1: 7$. The single box girder has a single room, and the beam has a depth of $1.4 \mathrm{~m}$, roof width of $5.0 \mathrm{~m}$ and floor width of $2.5 \mathrm{~m}$, both the roof and floor is $16 \mathrm{~mm}$ in thickness using steel Q345. Construction method is assembling erection. Fig 1 and fig 2(a) show the elevation view of the original steel bridge and the cross section of the girder.

PC footbridge. The PC footbridge, as a project for comparing, takes the same general arrangement of the steel bridge, variable cross-sections are used for the single-room single box girded of which the depth is $2.6 \mathrm{~m}$ and the width is $5 \mathrm{~m}$. the cross section at centre span has a $22 \mathrm{~cm}$ thick roof, a $25 \mathrm{~cm}$ thick floor and $32 \mathrm{~cm}$ thick webs and the cross section at supports has a $60 \mathrm{~cm}$ thick roof, a 60 $\mathrm{cm}$ thick floor and $80 \mathrm{~cm}$ thick webs, the cross section changes at the points $4.2 \mathrm{~m}$ to supports, the whole girder is made of concrete C50, Fig 2(b) shows the section of the main girder. Take $\varphi^{\mathrm{s}} 15.2$ 
strand as prestressed reinforcement, of which tensile strength are $1860 \mathrm{MPa}$ and $1260 \mathrm{MPa}$, and elastic modulus is $195 \mathrm{GPa}$. Full framing scheme is adopted for construction.

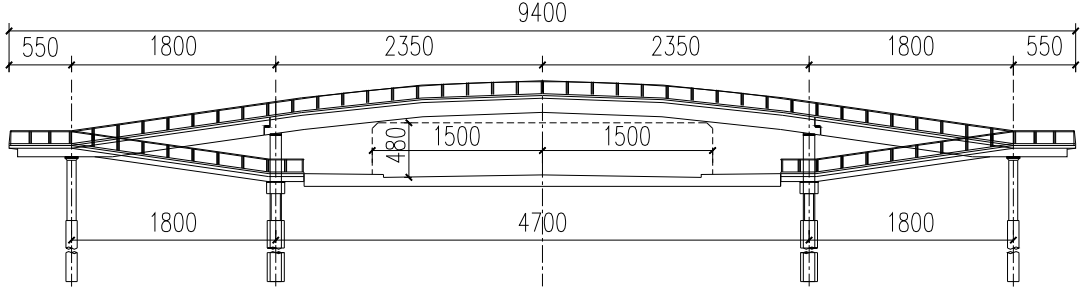

Fig.1 Elevation view of steel footbridge (Unit: $\mathrm{cm}$ )

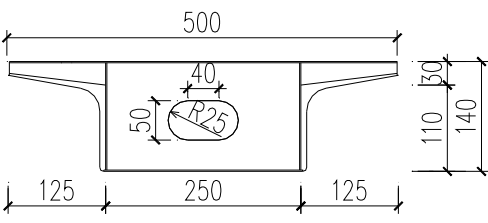

(a) Steel bridge

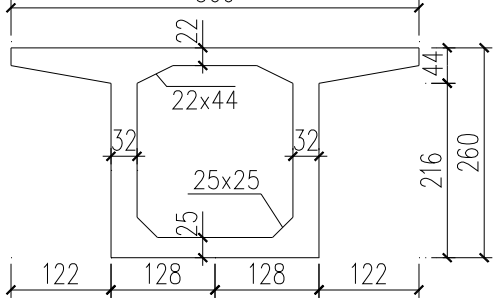

(b) PC bridge

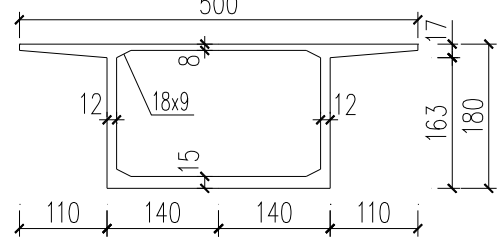

(c) RPC bridge

Fig.2 Box girder sections (Unit: $\mathrm{cm}$ )

\section{Trial design of RPC footbridge}

RPC footbridge has the same span arrangement with the original one, and also has a single-cell singer box cross section. he beam is $1.8 \mathrm{~m}$ deep and $5 \mathrm{~m}$ wide, section at centre span has a $8 \mathrm{~cm}$ thick floor, and a $15 \mathrm{~cm}$ thick bottom, $12 \mathrm{~cm}$ thick webs; section at support has a $32 \mathrm{~cm}$ thick roof, a 32 thick bottom and $40 \mathrm{~cm}$ webs, Fig 2(c) shows the section of the main girder. Compressive strength, tensile strength and elastic modulus of RPC are $120 \mathrm{MPa}, 17.5 \mathrm{MPa}$ and $42 \mathrm{GPa}$ respectively. The types of prestressed reinforcement in PC bridge and PRC bridge are same.

The RPC bridge uses precast segmental method for construction. First, cast-in-situ piers and temporary steel piers are set up, and the three segments of the main girder are prefabricated, after the preset strength value is reached, prefabricated segments are transported to the site to be erected and located, then RPC with wet joint is poured, after a day's natural curing, double PVC thin cover is used to led into $100^{\circ} \mathrm{C}$ steam for 3 days' curing, then external prestressing cables are tensioned and temporary piers are dismantled, the main part of bridge is constructed.

A finite element model has been created by MIDAS/CIVIL and structure has been simplified into simple-supporter structure with the exception of piers. 28 beam elements have been used to simulate the main girder and supports have been simulated by flexible coupling. Since the Shrinkage and Creep of concrete, temperature load, and foundation displacement cause no internal force for a simple beam, the factors that have been taken into principal consideration for the trial design are self-weight of the main girder, secondary paving and pedestrian load. The forces are combined according to CJJ 69-95 [6] and checked according JTG D62-2004. The calculating results show that the RPC bridge can meet the code requirements of bearing capacity, stress and deflection of main girder.

\section{Comparisons among RPC bridge, steel bridge and PC bridge}

Construction quantity and performance-price ratio. Specific strength and specific stiffness are two data that are often used to indicate material strength and stiffness, and defined as the ratio material strength and elastic modulus to specific density respectively. In order to make a comparison for performance-price ratio, material prices are introduced to the data mentioned above. Material strength efficiency $\gamma$ and material stiffness efficiency $\delta$ are defined as specific strength and specific stiffness per unit price; steel price is converted from each tons into each cubic meter. The material prices of steel bridge and PC bridge are provided by owners, the material price of RPC is estimated according to the cost when compounding the material in laboratory. 
Comparisons of material efficiency listed in Tab.1 demonstrate that the strength efficiency and the stiffness efficiency of RPC are 12.9 times and 6.6 times of the steel. In other words, RPC has a higher performance-price ratio than the original one; compared with the PC bridge, RPC girder obtains higher specific strength and specific stiffness, but it exhibits a poorer performance-price ratio for its higher price.

Tab.1 Material efficiency comparison of three girders

\begin{tabular}{|c|c|c|c|c|}
\hline \multicolumn{2}{|c|}{ Projects } & RPC & Concrete & Steel \\
\hline \multicolumn{2}{|c|}{ Density $\left(\mathrm{kg} / \mathrm{m}^{3}\right)$} & 2600 & 2400 & 7800 \\
\hline \multicolumn{2}{|c|}{ unit price of material (ten thousands Yuan $/ \mathrm{m}^{3}$ ) } & 0.358 & 0.035 & 3.9 \\
\hline \multirow{3}{*}{$\begin{array}{l}\text { strength } \\
\text { efficiency }\end{array}$} & Compressive strength (MPa) & 120 & 23.1 & 310 \\
\hline & Specific strength & 0.0462 & 0.0096 & 0.0397 \\
\hline & Material strength efficiency $\gamma$ & 0.0129 & 0.0274 & 0.001 \\
\hline \multirow{3}{*}{$\begin{array}{l}\text { Stiffness } \\
\text { efficiency }\end{array}$} & Elastic modulus $(\mathrm{GPa})$ & 42 & 34.5 & 210 \\
\hline & Specific stiffness & 0.0162 & 0.0144 & 0.0269 \\
\hline & Material stiffness efficiency $\delta$ & 0.0453 & 0.4114 & 0.0069 \\
\hline
\end{tabular}

Comparisons of the work quantity among the three girders manifest that the consumption of concrete and tendon correspond to RPC bridge is $82 \mathrm{~m}^{3}$ (reduces $56.4 \%$ compared with $187.9 \mathrm{~m}^{3}$ corresponds to PC bridge) and $7.2 \mathrm{t}$ (reduces $18.2 \%$ compared with $8.8 \mathrm{t}$ corresponds to PC bridge), the main reason is that RPC being a new type of cement material with high strength and performance, RPC bridge allows a thin cross section shape to be taken and less tendons to be used for meeting load-bearing requirements, its structural weight $(220.4 \mathrm{t})$ reduce $53.9 \%$ compared with PC bridge $(478.6 \mathrm{t})$.

The comparisons of the costs for girders indicate the costs for RPC girder, PC girder and steel girder are CHN 398 thousands, 217thousands and 652 thousands, RPC bridge costs a litter more than the PC bridge, whereas the cost for RPC bridge is 39.0\% lower than the steel bridge, which means that RPC bridge is of a relatively high performance-price ratio.

Construction performance. Construction performance of RPC bridge is between steel bridge and PC bridge. Segments of RPC bridge can be prefabricated in a factory and the weight of them is relatively lighter, when constructing with hoisting erection method, the construction period (19d) is half saved compared with the PC bridge (38d) and the influence imposed on the main traffic is slight; when it is compared with the steel bridge (12d), the construction lasts a longer time than the steel bridge and is relatively complex for the existing of wet joint.

Mechanical properties. 1) The dead load and the dead-live load ratio. The self-weight of main girder in RPC bridge is $220.4 \mathrm{t}$ between $130.3 \mathrm{t}$ of the steel bridge and $478.6 \mathrm{t}$ of the PC bridge, the dead-live load ratio of RPC bridge is 3.55 , only $5 / 9$ of the PC bridge (6.30), and a little greater than that (2.80) of the steel bridge of which the members in compression have problems of local stability, and additional materials will be consumed for the stiffener.

2) Shear bearing performance. Shear strength of RPC can reach $20 \sim 30 \mathrm{MPa}$, which is 8 to 12 times of normal concrete $(1.3 \sim 2.5 \mathrm{MPa})$ [7]. Therefore, RPC bridge can reduce or even cancel the shear reinforcement. The calculation shows that for the RPC bridge, the ratio of shear bearing capacity to shear effect is $3011 \mathrm{kN} / 2139 \mathrm{kN}=1.4$; for the PC bridge, the value is $4621 \mathrm{kN} / 3635 \mathrm{kN}$ $=1.3$, the one of RPC bridge is a little greater than the one of PC bridge, in other words, shear bearing capacity of a RPC bridge without shear reinforcement performances better than that of the PC bridge with shear reinforcement.

3) Cracking resistance property. RPC owns a tensile strength of $20 \mathrm{MPa}$, which is 10 times higher than that of normal concrete $(0.9 \sim 2.0 \mathrm{MPa})$. The crack in RPC girder increases at a very low speed for the sake of the reinforcement and crack-resistance effect provided by fiber steer after the concrete in tensile region begins to crack, the tensile stress being transferred to fiber steers, they do not lose bearing capacity until plucked out. The ductility failure makes non-prestressed reinforcement 
unnecessary in RPC bridge designs, which greatly reduces steel consumption and concreting difficulty .

4) Durability property. RPC bridge has shown excellent durability property. For PC bridge, because of its poor durability, corrosion and carbonation will occur and structural stability is influenced, the service life of the bridge is thus greatly shortened. For steel bridge, in order to improve the durability, anticorrosive treatment need to be taken and manpower and resources are expended in the maintenance. With excellent penetration-resistant, freezing and thawing resistance, antifreeze, carbonation-resistance and corrosion-resistance of RPC material [8], RPC footbridge will overcome defects of PC bridge and steel bridge, attain or even extend the design service period. The spending for maintenance is thus saved to achieve huge economic and social benefits.

\section{Conclusions}

Trial design of an RPC footbridge with a $47 \mathrm{~m}$ long main span has been conducted. The conclusions are drawn as follow: compared with steel bridge, RPC bridge obtains a higher material strength efficiency and stiffness efficiency, while the cost of material gets a 39\% decrease, which means RPC bridge has a higher performance-price ratio; when the Comparison comes to PC bridge, RPC bridge exhibits a higher material strength efficiency and stiffness efficiency with an decrease of $56.4 \%$ on concrete consumption, $18.2 \%$ on prestressed reinforcement consumption and $53.9 \%$ on dead weight of structure, RPC footbridge has advantages of construction, economy and mechanical property, and is quite feasible for engineering.

\section{References}

[1] P Richard, M Cheyrezy. Composition of Reactive Powder Concretes. Cement and Concrete Research, 1995, 25(7): 1501-1511.

[2] Du Renyuan, Huang Qingwei, Chen Baochun. Experimental studies on strength and cost of RPC . Proceedings of 7 th Central European Congress on Concrete Engineering. Balatonfüred, Hungary, 2011: 137-140.

[3] O.Bonneau, M.Lachemi. Mechanical Properties and Durability of Tow Industrial Reactive Powder Concrete. ACI Material Joumal, 1997, 7(8): 25-28.

[4] Suk-Bum Huh, Yoon-Joo Byun. Sun-Yu Pedestrian Arch Bridge, Seoul, Korea. Structural Engineering International, 15(1), 2005: 32-34.

[5] Jure Radic, Alex Kindij, Ana Mandic. History of Concrete Application in Development of Arch Bridges. Proceedings of the Chinese-Croatian Joint Colloquium organized by Unisity of Zagred Faculty of Civil Engineering \& Fuzhou University College of Civil Engineering Brijuni Islands, Croatia, July10-14, 2008: 9-76.

[6] Technical Specifications of Urban Pedestrian Overpass and Underpass (CJJ69-95). Beijing: China Construction and Industry Press, 1996.

[7] YAN Jianping. Research on shear bearing strength of Reactive Powder Concrete materials . Master Thesis , Beijing: Beijing Jiaotong University, 2011.

[8] O Bonneau, M Lachemi, Eric Dallaire, et al. Mechanical Properties and Durability of Two Industrial Reactive Powder Concretes. ACI Materials Journal, 1997, 94(4): 286-290. 